\title{
Factors Determining Household Consumer's Willingness to Pay for Water Consumption in Malaysia
}

\author{
Nabsiah Abdul Wahid ${ }^{1} \&$ Chew Kah Hooi ${ }^{1}$ \\ ${ }^{1}$ Graduate School of Business, Universiti Sains Malaysia, Pulau Pinang, Malaysia \\ Correspondence: Nabsiah Abdul Wahid, Graduate School of Business, Universiti Sains Malaysia, 11800 Pulau \\ Pinang, Malaysia. Tel: 60-46-53-5161. E-mail: nabsiah@hotmail.com; nabsiah@usm.my
}

Received: August 4, 2014

Accepted: September 22, 2014 Online Published: February 12, 2015

doi:10.5539/ass.v11n5p26

URL: http://dx.doi.org/10.5539/ass.v11n5p26

\begin{abstract}
Since Malaysia's most recent water reform exercise, the issue on whether Malaysian public (households) would be willing to pay for possible new water tariff in return for services provided for them has arisen. This study investigates whether taste, filtered water, color, water contamination, drinkable tap water, customer services, uninterrupted water supply and income determine Malaysian consumer's willingness to pay (WTP) for their household water consumption. A survey was carried out on more than 262 representing households who are also paid domestic water customers. Multiple regression analyses results showed that only four from the eight factors examined were significant and acted as determinants to WTP. These are taste, uninterrupted water supply, water contamination and income. The study also found that majority of household consumers is only willing to pay for an increase of not more than RM5 from their current water bill. The findings provide an insight particularly for the government and water services providers in Malaysia on factors that they should consider when planning for any water tariff increase.
\end{abstract}

Keywords: consumers, health risk, Malaysia, water quality, willingness to pay (WTP)

\section{Introduction}

Acknowledging water as a scarce resource is why securing and providing safe drinking water for the public becomes top priority for governments around the world and Malaysia is not excluded. Amongst the many initiatives on safe drinking water provision that the country implements include the continuing five-year Malaysia Plans series to ensure the quality of life of its citizens is improved. Despite the efforts, the public still experiences water related problems like oil spillage, bacteria contamination in the rivers used for water intake and water disruption. In August 2013 for instance, oil spillage in Selangor River caused four water treatment plants in the Selangor state to temporary shut downs that led to a major water supply disruption for millions of household consumers and businesses (Au \& Mokhtar, 2013). Another May 2014 incident not only pollutes the Batu Ferringhi River in Penang with sewage treatment plant discharges but also contaminates it with E. Coli (Ngui, 2014). These incidents amongst other factors not only affected the public's perception about water services providers (mostly states) and water provided for their needs but also about whether they will be willing to pay (WTP) for the services they are provided with at an increased tariff.

In the most recent water restructuring exercise, the issue on abolishment of government's subsidies has been suggested. To date, the government has been shouldering some of the water delivery process costs incurred which is claimed to lead to inefficient water resources management by the services providers in the country. The government intended to adopt Full Cost Recovery (FCR) approach to enable for all of related costs to be recovered when water is delivered to customers as opposed to the cost-plus approach that are currently applied by water service providers in Malaysia. Subsidies dependent has in some way caused many states to operate inefficiently. With the new approach, it is hoped that the states as water services providers will be able to efficiently manage their water operation and cover any losses by closing the gap between actual costs that they incurred and water tariff or price that the public pays. This means that Malaysian public will be responsible to pay for the "efficient" cost of delivering water services that they consume (SPAN, 2008) rather than burdening the cost to the government which needs to be covered via subsidies. This also means that the possibility for water tariff to be increased by water services providers in the country will be most likely in the near future. 
Since some stakeholders are of the opinion that water is a social good rather than an economic good, the question on whether the Malaysian public will be willing to pay for water tariff increase when they have enjoyed the benefits of subsidies over the years comes into the picture. To answer this question, there is a need to find out and identify the determining factors that will lead Malaysian public (household consumers) to willingly pay for their water consumption as attempted by this study. Using factors that have been used in previous literature, this study hypothesize that water taste quality, filtered water, color of water, perceived health risk due to water contamination, perceived health risk due to tap water provided, customer services, uninterrupted water supply and household's income act as the determinants towards Malaysian consumer's willingness to pay (WTP) for their household water consumption.

\section{Literature Review}

The idea of user as funder to water that they consume has been supported in the literature. Engel, Pagiola, and Wunder (2008) suggest for the traditional government's funding on water supply be transformed to the user's funding as a way to help the industry to grow. As explained by David (2008) in conventional government funding approach, it is the government who is responsible and becomes the provider for financing of building treatment plants, reservoirs, pumping station and distribution piping to ensure water can be delivered to the public consumers. In short, all intensive capital expenditures are subsidized by the government in question in addition to the opinion that such government is treating water as a social good rather than an economic good.

Jiang, Jin, and Lin (2010) explain how the basic idea in user funding is to enable water operators or providers (like the government) to obtain additional funds through the increase of water tariff. The raised funds will then be distributed for water management purposes like pollution control at upstream watercourse, water treatment, operation and maintenance. The extra fund from the new increased tariff is needed basically because water tariff paid by consumers generally does not consider the opportunity cost of capital. To be able to provide quality water services to consumers, higher water tariff or price needs to be implemented since higher level of water services and water quality is only attainable through higher costs (Hensher, Shore, \& Train, 2005). In addition, higher water price or tariff is argued in the literature as effective method in ensuring scarce resources like water to be properly valued by consumers which will also lead them towards sustaining efficient utilization and preventing wastage (Bogale \& Urgessa, 2012). This is critical in a country like Malaysia where water tariffs are still considered low compared to other countries. For example, Penang state is identified as the state in Malaysia that offers the lowest water tariff with RM $0.22 / \mathrm{m}^{3}$ (for $0-20 \mathrm{~m}^{3}$ ) and RM $0.42 / \mathrm{m}^{3}$ (for $>20-40 \mathrm{~m}^{3}$ ).

\subsection{Willingness to Pay (WTP) and Attribution Theory}

Willingness to pay is defined as the highest price that an individual is willing or accept to pay for some goods or services (Breidert, 2006). An individual's willingness to pay can be easily tied to the Attribution Theory which suggests that an individual's psychological state is a consequence of his/her evaluation of causal factors (Weiner, $1985 \mathrm{~b}, 2000$ ); whereby one dominant psychological consequence of the causal factors is a cognitive variable referred to as the expectancy of success (Weiner, 1985a, 1985b). In general, this theory suggests that when an individual identifies the causal factors of success, $\mathrm{s} / \mathrm{he}$ believes that $\mathrm{s} / \mathrm{he}$ can successfully act upon these factors and increase his/her probability of success. Thus, higher expectations of success are derived from an individual's belief in his/her ability to successfully capitalize on the underlying causal factors that $\mathrm{s} / \mathrm{he}$ has identified as the influencer of his/her success. The expectancy of success motivates an individual to leverage causal factors through his/her behaviors resulting in higher levels of success (Anderson, 1983). For instance, a household may be willing to pay higher for an improved water value from the belief that they are at the moment consuming poor water value or otherwise. It is less likely however that a household will be willing to pay for improving source quality when the perceived quality is higher.

\subsection{Willingness to Pay (WTP) and Determining Factors}

The literature has identified some variables that have been used in past studies like an improved water quality (e.g. taste) that is linked to household's willingness to pay investigation. Households were commonly found to be willing to pay higher for improved water quality from most of the studies. According to Doria (2010), organoleptics especially taste relates to sensorial information which affects public's perception of water quality. Beaumais, Briand, Millock, and Nauges's (2010) cross-country valuation study on household's WTP found that respondents who faced problem with taste in water or health concerns related to drinking water are willing to pay higher for better water quality. Doria (2010) noted Warren's (1996) study findings whereby in western countries, water taste is usually more important than odor or appearance, which may due to detection of taste of water chemical at lower concentration than other senses. 
Households in Fuzhou, China are also found willing to pay an additional 10\% from the current water tariff they are paying to control pollution of the water source (Jiang et al., 2010). A similar finding is found for people in a district in Southern Ethiopia who are willing to pay 1.5 times higher than the current water charges they are facing (Behailu, Kume, \& Desalegn, 2012). Cho, Easter, McCann, and Homans's (2005) study found that rural residents in Minnesota are willing to pay to improve their drinking water quality by reducing the iron and sulfate concentration in the water. However, willingness to pay is less for consumers that perceive they are provided with good quality water. Interestingly, Genius et al.'s (2008) study found that on average, willingness to pay is less for consumers who perceived that their water quality is unsatisfactory as well as for those who complain about water chlorine smell, mainly because these consumers believe that chlorine smell is not likely to be improved.

A review of outbreaks related to sources of drinking water over a 27-year period in Canada for example concluded that two-third of these water-borne illnesses were related to either semi-private or private drinking water supplies (Charrois, 2010). This study identified chemical contamination as another challenge to source of potable water. Contamination by nitrate and pesticides often occur near to agricultural area. In Pakistan, a study on willingness to pay for water borne diseases interventions in rural communities of Lahore found only $26 \%$ of the population are willing to pay for piped-line water supply at US3.6 per month (Malik, Yasar, Tabinda, \& Abubakar, 2012). The same study also found that only $36 \%$ of the respondents surveyed were aware that diarrhea and malaria were water-borne disease. This may be the reason for why the results were as they were. However, willingness to pay is found to increase when respondents' income were above poverty level.

In a study investigating consumer risk perceptions and attitudes towards water quality and infrastructure by Tanellari, Bosch, and Mykerezi (2009), it was found that as individuals become more risk averse, their willingness to reduce the risk increases. The main consumer's complaints are observed to be very much related to an increasing number of leaks in drinking water pipes due to copper corrosion as well as breaks in the water main due to aging (Scardina, Edwards, Bosch, Loganathan, \& Dwyer, 2008).

Some studies in the literature suggest that improvement of water service through uninterrupted water supply is crucial in developing countries (Baisa, Davis, Salant, \& Wilcox, 2010; Whittington, Pattanayak, Yang, \& Kumar, 2002). Urban household residents in wealthier countries such as Australia are found to be willing to pay to reduce the frequency and duration of water service interruptions; however, willingness to pay is lower when households face more interruption per year (Hensher et al., 2005). In addition, willingness to pay is bound to diminish when a culture of unreliable water supply services takes place as argued by Dutta and Verma (2009) mainly because households have to invest a significant amount of money to buy large water storage in the attempt to avoid unreliable water supply. Many studies are found to report a lower willingness to pay in the cases where households have uninterrupted water supply, clean and safe water, and reliable water (Akram \& Olmstead, 2011; Fujita, Fujii, Furukawa, \& Ogawa, 2005; Olanrewaju, Cecilia, Omonona, \& Titus, 2012; Vasquez, Mozumder, hernandez-Arce, \& Berrens, 2009; Wang, Xie, \& Li, 2010).

The literature also reports on the probability of approving increase in water tariff when household's income is increased (Bogale \& Urgessa, 2012; Cho et al., 2005; Genius et al., 2008; Jiang et al., 2010; Wendimu \& Bekele, 2011). The households' income has significant impact on WTP.

The importance of customer service center is acknowledged in the literature as the center that helps to handle feedback, complaint and request from consumers. Hensher et al. (2005) report on urban country respondents' preference to have a person answer the phone when they call the service center rather than having a voice system provide a message; and that they are willing to pay for this service feature. In addition, willingness of acceptance among consumers can be achieved through a provision of information about production process of water treatment (Dolnicar, Hurlimann, \& Nghiem, 2010) and accessibility to information like a public visit to water treatment plant to foster confidence towards service providers (Doria, 2010).

\section{Methodology}

The study was designed to be empirical in nature. A survey was carried out on Malaysian households from different states in the country who are paid domestic water users. Survey questionnaires were given to household's representatives who were available at the selected service counters and post offices in the states within the one month data collection exercise were carried out by the researchers. The respondents were people who were found paying for their household's water bill at the premises and who were also willing participants to the study. The self-administered questionnaires were collected back the minute the volunteered respondents finished filling them up. The questionnaire was designed to be structured in nature. It was divided into several sections that include household's demographic and socio-economic profiles and respondent's opinions in regards 
to the determinant variables investigated in the study (e.g. water taste, health risk concern caused by water contamination, customer services, and willingness to pay). Respondent's responses to all item statements were measured using a 7 point Likert-type scale from "strongly disagree" (1) to "strongly agree" (7). Multiple regression analysis was chosen as the method to test all eight hypotheses concerning the assumed determining factors on household consumer's WTP.

\section{Results and Discussions}

Of the total of 500 survey questionnaires distributed to Malaysian households, 280 (or 56\%) were returned and of these, only $262(52 \%)$ were found usable for further analysis.

Respondents' profile analyses (refer Table 1) reveal majority of household consumers are those who live at suburban areas (51.5\%), of the male gender (53.1\%), those between the age group of 24 to 35 years old (42.4\%), those with Bachelor degrees (44.7\%), those earning a household monthly income between RM3000 and RM6000 (32.1\%), and those who come from a household size of between two to four persons (47.7\%). It is also found that most of the household consumers (19.5\%) surveyed pay their water bill between RM15 to RM35. It is important to note that each water bill statement is for a two months' consumption.

As for how much the respondents are willing to pay for additional charges to what they are paying on their current water bill in return for improved water quality and water services, it is found that the majority (41.2\%) choose to pay additional charges of less than RM5. It is important to note that there are $15.6 \%$ of the respondents who indicated that they are not willing to pay any additional charges at all although they know the extra is for improved water quality and services.

Table 1. Respondents' profile

\begin{tabular}{|c|c|c|c|}
\hline & Description & Frequency & Percentage \\
\hline \multirow{3}{*}{ Home Area } & Rural & 48 & 18.3 \\
\hline & Suburban & 134 & 51.1 \\
\hline & Urban & 80 & 30.5 \\
\hline \multirow{3}{*}{ Gender } & Male & 139 & 53.1 \\
\hline & Female & 123 & 46.9 \\
\hline & Below 24 years & 37 & 14.1 \\
\hline \multirow{5}{*}{ Age } & 24 to 35 years & 111 & 42.4 \\
\hline & 36 to 45 years & 75 & 28.6 \\
\hline & 46 to 55 years & 27 & 10.3 \\
\hline & Above 55 years & 12 & 4.6 \\
\hline & Secondary School & 62 & 23.7 \\
\hline \multirow{4}{*}{$\begin{array}{l}\text { Highest Education } \\
\text { Level }\end{array}$} & Certificate/Diploma & 77 & 29.4 \\
\hline & Bachelor Degree & 117 & 44.7 \\
\hline & Master Degree & 6 & 2.3 \\
\hline & Below RM 1500 & 49 & 18.7 \\
\hline \multirow{4}{*}{ Monthly Income } & RM1500 to RM3000 & 76 & 29.0 \\
\hline & $>$ RM3000 to RM6000 & 84 & 32.1 \\
\hline & $>$ RM6000 to RM9000 & 40 & 15.3 \\
\hline & $>$ RM9000 & 13 & 4.9 \\
\hline \multirow{4}{*}{ Current water bill } & RM15 and below & 57 & 21.7 \\
\hline & $>$ RM15 to RM 35 & 99 & 37.8 \\
\hline & $>$ RM35 to RM55 & 56 & 21.4 \\
\hline & $>$ RM55 & 50 & 19.1 \\
\hline \multirow{5}{*}{ Household Size } & Only 1 person & 7 & 2.7 \\
\hline & 2 to 4 persons & 125 & 47.7 \\
\hline & 5 to 7 persons & 99 & 37.8 \\
\hline & 8 to 10 persons & 24 & 9.2 \\
\hline & $>10$ persons & 7 & 2.7 \\
\hline \multirow{6}{*}{$\begin{array}{l}\text { Willingness to pay } \\
\text { for additional } \\
\text { charges on top of } \\
\text { water bill (RM) }\end{array}$} & nothing & 41 & 15.6 \\
\hline & $<$ RM5 & 108 & 41.2 \\
\hline & RM5 - RM10 & 80 & 30.5 \\
\hline & RM11 - RM15 & 25 & 9.5 \\
\hline & RM16 - RM20 & 4 & 1.5 \\
\hline & $>$ RM20 & 4 & 1.5 \\
\hline
\end{tabular}


Results for regression analyses carried out are presented in Table 2. As can be seen, the results of the analyses indicated that out of Income, Water Taste Quality, Water Color Quality, Filtered Water Quality, Drinking Tap Water Health Risk; Water Contamination Risk, Uninterrupted Water Supply, and Customer Service that have been hypothesized as the determinants for Household Customer's Willingness to Pay, only four of them are significant. These are Income, Water Taste Quality, Water Contamination Risk, and Uninterrupted Water Supply.

Table 2. Regression analysis for determining variables and willingness to pay (WTP)

\begin{tabular}{|c|c|c|c|c|c|c|}
\hline \multicolumn{7}{|c|}{ Coefficients $^{\mathrm{a}}$} \\
\hline & \multirow{2}{*}{ Model } & \multicolumn{2}{|c|}{ Unstandardized Coefficients } & \multirow{2}{*}{$\begin{array}{c}\text { Standardized Coefficients } \\
\text { Beta }\end{array}$} & \multirow{2}{*}{$\mathrm{t}$} & \multirow{2}{*}{ Sig. } \\
\hline & & $\mathrm{B}$ & Std. Error & & & \\
\hline & (Constant) & .793 & .848 & & .935 & .351 \\
\hline & Income & .286 & .085 & .204 & 3.346 & .001 \\
\hline & aveWT $^{1}$ & .208 & .090 & .152 & 2.302 & .022 \\
\hline & aveWCO $^{2}$ & -.002 & .083 & -.002 & -.027 & .979 \\
\hline \multirow[t]{5}{*}{1} & aveWFil $^{3}$ & -.073 & .064 & -.081 & -1.154 & .250 \\
\hline & aveDTw $^{4}$ & .046 & .059 & .049 & .770 & .442 \\
\hline & aveHRCon $^{5}$ & .213 & .094 & .165 & 2.249 & .025 \\
\hline & aveWSSP $^{6}$ & .118 & .055 & .131 & 2.148 & .033 \\
\hline & aveWSC $^{7}$ & .098 & .055 & .110 & 1.781 & .076 \\
\hline
\end{tabular}

a. Dependent Variable: Willingness to Pay (AVEWTP); ${ }^{1}$ Water Taste; ${ }^{2}$ Water Color; ${ }^{3}$ Filtered Water; ${ }^{4}$ Drinking Tap Water; ${ }^{5}$ Water Contamination risk; ${ }^{6}$ Uninterrupted water supply; ${ }^{7}$ Customer service

As the multiple regression analyses results show, only four out of the eight determinants found to be significant although all of these determinants are those taken and acknowledged in the literature. Water taste, health risk due to water contamination, uninterrupted water supply and income are found to be the determinants of household's willingness to pay in this study are already expected and are in line with previous studies. The literature for example has reported on the importance of water taste compared to odor and color (Doria, 2010; Warren, 1996), on how water users are willing to pay more for better water taste (e.g. Beaumais et al. 2010), to reduce water contamination (Cho et al., 2005; Khan, Iqbal, Saeed, \& Khan, 2010; Malik et al., 2012) and to be provided with uninterrupted water supply (Baisa et al., 2010; Hensher et al., 2005; Olanrewaju et al., 2012; Vasquez, 2009).

It is quite surprising to find that other determinants hypothesized i.e., the color of drinking water, filtered water, tap water, and customer service are not considered significant by Malaysian households on their willingness to pay for water. Some of the past studies had been carried out in rural areas which means that the residents participated in the investigation have to obtain water from other sources such as from the well or river. Therefore, they may have many problems in securing safe drinking water for their household consumption. In the case of this current study, the majority of the respondents are from suburban and urban areas. In Malaysia, it is a well-known fact that particularly in areas like this, houses are supplied with continuous, quality, clean, and safe drinking water by the state/water service provider. These may be the reasons for why the determinants like color, filtered water, tap water, customer service are non-issues for them that lead to the insignificant results as found in this study.

The current study found that income is also a determinant for household customer's willingness to pay which is in line with past research (e.g. Bogale \& Urgessa, 2012; Cho et al., 2005; Genius et al., 2008; Jiang et al., 2010; Wendimu \& Bekele, 2011). Here, it is assumed that when household's income is increased, there should be an increase in the household's willingness to pay for water no matter the amount.

The study findings have suggested that willingness to pay is a result of various determinants or attributes that are psychologically important to the household customers which supports the use of Attribution Theory for a study like this. In this study's case for example, customer's willingness to pay is found to be equated or capitalized to water taste, avoidance of water contamination that provides health risk, uninterrupted water supply and their income.

\section{Conclusions}

The study concludes that Malaysian households consider income, water taste, water contamination and continuous water supply as determinants for their willingness to pay. The findings imply that the government and water service providers really need to focus on the four determinants when they are strategizing for new 
water tariff. As water service providers, it is important to note that customers are not willing to pay a hefty price for their water bill. The study has identified that any increment should not be more than RM5 from the current customer's water bill. This study has helped to establish the basic needs required by Malaysia's domestic water users (household's customers) if water tariff is to be increased. Since continuous water supply, reducing water contamination risk and water taste are major determinants of willingness to pay for water in Malaysia, the water service providers should be strategizing for efficient water management to take place particularly by providing customers with uninterrupted water supply even during drought season. In terms of water rate adjustment, this study has provided a baseline on the significant influence of customer's income on their willingness to pay. This study can be extended further by focusing specifically on each state in Malaysia as each one is charging different water tariff to their customers.

\section{Acknowledgements}

The authors would like to extend their appreciation to the Ministry of Education Malaysia for the research grant provided under the Long Term Research Grant Scheme (LRGS) 203/PKT/6726002, Universiti Sains Malaysia and those who have took part and provided us with information for this study.

\section{References}

Akram, A. A., \& Olmstead, S. M. (2011). The value of household water service quality in Lahore, Pakistan. Environmental \& Resouce Economics, 49, 173-198. http://dx.doi.org/10.1007/s10640-010-9429-7

Anderson, C. A. (1983). The causal structure of situations: The generation of plausible causal attributions as a function of the type of event situation. Journal of Experimental Social Psychology, 19, 185-203. http://dx.doi.org/10.1016/0022-1031(83)90037-9

Au, E., \& Mokhtar, I. L. (2013, August 31). Oil spill causes water cuts to 1m consumers in KL, Selangor. New Straits Times.

Baisa, B., Davis, L., Salant, S., \& Wilcox, W. (2010). The welfare costs of unreliable water service. Journal of Development Economics, 92, 1-12. http://dx.doi.org/10.1016/j.jdeveco.2008.09.010

Beaumais, O., Briand, A., Millock, K., \& Nauges, C. (2010). What are households willing to pay for better tap water quality? A cross-country valuation study (pp. 1-37). Documents de travail du Centre d'Economiie de la Sorbonne 2010.51 - ISSN : 1955-611X.2010. <halshs-004977453>.

Behailu, S., Kume, A., \& Desalegn, B. (2012). Household's willingness to pay for improved water service : a case study in Shebedino District, Southern Ethiopia. Water and Environmental Journal, 1-6.

Bogale, A., \& Urgessa, B. (2012). Households' willingness to pay for improved rural water service provision: Application of contigent valuation method in Eastern Ethiopia. Journal of Human Ecology, 38(2), 145-154.

Breidert, C. (2006). Estimation of Willingness-to-Pay: Theory, Measurement, Application. Germany: Gabler Edition Wissenschaft.

Charrois, J. W. A. (2010). Private drinking water supplies: Challenges for public health. Canadian Medicl Association Journal, 182(10), 1061-1064. http://dx.doi.org/10.1503/cmaj.090956

Cho, Y., Easter, K. W., McCann, L. M. J., \& Homans, F. (2005). Are rural residents willing to pay enough to improve drinking water quality? Journal of The American Water Resources Association, 41(3), 729-740. http://dx.doi.org/10.1111/j.1752-1688.2005.tb03767.x

David, L. B. (2008). A Framework for Analyzing Tariffs and Subsidies in Water Provision to Urban Households in Developing Countries. USA. Retrieved February, 2, 2013, from http://www.un.org/esa/desa/papers/ 2008/wp63_2008.pdf

Dolnicar, S., Hurlimann, A., \& Nghiem, L. D. (2010). The effect of information on public acceptance-The case of water from alternative sources. Journal of Environmental Management, 91, 1288-1293. http://dx.doi.org/10.1016/j.jenvman.2010.02.003

Doria, M. F. (2010). Factors influencing public perception of drinking water quality. Water Policy, (12), 1-19. http://dx.doi.org/10.2166/wp.2009.051

Dutta, V., \& Verma, N. M. P. (2009). Water pricing, affordability and public choice: An economic assessment from a large Indian Metropolis. International Journal of Economics and Finance, 1(2), 238-252. http://dx.doi.org/10.5539/ijef.v1n2p238

Engel, S., Pagiola, S., \& Wunder, S. (2008). Designing payments for environmental services in theory and 
prictice: An overview of the issues. Ecological Economics, 663-674.

Fujita, Y., Fujii, A., Furukawa, S., \& Ogawa, T. (2005). Estimation of willingness-to-pay for water and sanitation services through contingent valuation method: A case study in Iquitos City, The Republic of Peru (pp. 59-87). Japan Bank International Cooperation Institute.

Genius, M., Hatzaki, E., Kouromichelaki, E. M., Kouvakis, G., Nikiforaki, S., \& Tsagarakis, K. P. (2008). Evaluating consumers' willingness to pay for improved potable water quality and quantity. Water Resource Management, 22, 1825-1834. http://dx.doi.org/10.1007/s11269-008-9255-7

Hensher, D., Shore, N., \& Train, K. (2005). Households' willingness to pay for water service attributes. Environmental \& Resouce Economics, 32, 509-531. http://dx.doi.org/10.1007/s10640-005-7686-7

Jiang, Y., Jin, L., \& Lin, T. (2010). Higher water tariffs for less river pollution-evidence from Min River and Fuzhou City, People's Republic of China. Philippines.

Malik, A., Yasar, A., Tabinda, A. B., \& Abubakar, M. (2012). Water-borne diseases, cost of illness and willingness to pay for diseases interventions in rural communities of developing countries. Iranian Journal of Public Health, 41(6), 39-49.

Ngui, A. (2014). DOE identifies pollutant source. the Sun daily. Retrieved May 1, 2014 from http://www.thesundaily.my/news/974091

Olanrewaju, Cecilia, E., Omonona, \& Titus, B. (2012). Determinants of households' willingness to pay for improved water supply service in Kosofe Local Government Area of Lagos State. Continental J. Sustainable Development, 3(3), 20-31.

Scardina, P., Edwards, M., Bosch, D. J., Loganathan, G. V., \& Dwyer, S. K. (2008). Assessment of non-uniform corrosion in copper piping (p. 174). Denver: American Water Works Association Research Foundation.

SPAN. (2008). SPAN Business Plan 2008-2010 (pp. 1-21). SPAN.

Tanellari, E., Bosch, D., \& Mykerezi, E. (2009). A study on consumers' attitudes and willingness to pay for improved drinking water quality and infrastructure. Paper presented at the AAEA \& ACCI Joint Annual Meeting, Milwaukee, Wisconsin.

Vasquez, W. F., Mozumder, P., hernandez-Arce, J., \& Berrens, R. P. (2009). Willingness to pay for safe drinking water: Evidence from Parral, Mexico. Journal of Environmental Management, (90), 3391-3400. http://dx.doi.org/10.1016/j.jenvman.2009.05.009

Wang, H., Xie, J., \& Li, H. (2010). Water pricing with household surveys: A study of acceptability and willingness to pay in Chongqing, China. China Economic Review, 21, 136-149. http://dx.doi.org/10.1016/j.chieco.2009.12.001

Warren, L. (1996). Linking customer satisfaction to performance measures. Paper presented at the Proceedings of the Annual Conference; Management and Regulations.

Weiner, B. (1985a). An attributional theory of achievement motivation and emotion. Psychological Review, 92(4), 548-573. http://dx.doi.org/10.1037/0033-295X.92.4.548

Weiner, B. (1985b). An Attributional Theory of Motivation and Emotion. New York: Springer.

Weiner, B. (2000). Attributional thoughts about consumer behavior. Journal of Consumer Research, 27(3), 382-387. http://dx.doi.org/10.1086/317592

Wendimu, S., \& Bekele, W. (2011). Determinants of individual willingness to pay for quality water supply: The case of Wonji Shoa Sugar Estate, Ethiopia. Journal of Ecology and the Natural Environment, 3(15), 474-480.

Whittington, D., Pattanayak, S. K., Yang, J. C., \& Kumar, K. C. B. (2002). Household demand for improved piped water services: Evidence from Kathmandu, Nepal. Water Policy, 4, 531-566. http://dx.doi.org/10.1016/S1366-7017(02)00040-5

\section{Copyrights}

Copyright for this article is retained by the author(s), with first publication rights granted to the journal.

This is an open-access article distributed under the terms and conditions of the Creative Commons Attribution license (http://creativecommons.org/licenses/by/3.0/). 